\title{
ОПЫТ ПОЛУЧЕНИЯ ВТОРИЧНОГО ЛИТОГО ПОЛИКРИСТАЛЛИЧЕСКОГО КРЕМНИЯ И ПОЛУПРОВОДНИКОВЫХ ПРИБОРОВ НА ЕГО ОСНОВЕ
}

\author{
Б.М. Абдурахманов ${ }^{1}$, А.Л. Кадыров ${ }^{2}$ \\ ${ }^{1}$ Институт ионно-плазменных и лазерных технологий им. УА Арифова АН РУз, ул. Дурмон \\ йули 33, 100125 Ташкент, Узбекистан; bogarab@mail.ru \\ ${ }^{2}$ Худжандский государственный университет им. Б. Гафурова, пер. Мавлонбекова 1, 735700 \\ Худжанд, Таджикистан; abdulakhatkadirov@gmail.com
}

(Получена 16.10.2019)

\begin{abstract}
Иккиламчи қуйма поликристалл кремний технологиясини ва шунинг асосида куёш элементларини хุамда бошқุа яримўтказгичли асбобларни яратиш бўйича қилинган мажмуавий ишлар натижалари келтирилган. Махєаллий хом ашёдан фойдаланиб техник кремний ишлаб чикุаришни ўзлаштиришнинг истик̨боллари кўриб чиқ̣илган.

Приведены результаты комплекса работ по технологии вторичного литого поликристаллического кремния и созданию на этой основе солнечных элементов и других полупроводниковых устройств. Рассмотрены перспективы освоения производства технического кремния с использованием местного сырья.
\end{abstract}

The results of a set of works on the technology of secondary cast polycrystalline silicon and the creation on this basis of solar cells and other semiconductor devices are presented. The prospects of mastering the production of industrial silicon using local raw materials are considered.

В начале последнего десятилетия прошлого века оборонные предприятия бывшего СССР столкнулись с проблемой сворачивания заказов на изделия специального назначения. Предпринимаемые меры по их замене на товары народного потребления оказались недостаточными, и тогдашнее руководство завода «Алмос» г. Худжанда и Ленинабадского комбината редких металлов (ЛКРМ) в пгт. Чойрух-Дайрон Согдийской области предприняли шаги по освоению производства новых изделий в рамках конверсии оборонных заказов. Завод «Алмос» специализировался на выпуске кварцевых резонаторов и фильтров, 87\% из которых предназначались на нужды обороны. На ЛКРМ, наряду с выплавкой редких металлов, отливали поликристаллические кремниевые матрицы из отходов ряда кремниевых производств. Производство резонаторов включало в себя операции, по своей сути не отличавшиеся от регламента изготовления солнечных элементов (СЭ) с различием только в режимах операций. Исключение составляла только операция диффузии, поэтому было принято решение освоить операцию диффузии примесей в кремний, изготовить недостающую оснастку контрольно измерительными приборами и наладить на имеющемся оборудовании завода «Алмос» выпуск СЭ с использованием в качесте сырья литого поликристаллического кремния производства ЛКРМ. Для этого установку для литья кремниевых матриц на ЛКРМ подвергли переделке под выпуск слитков параллелепипедной формы с размерами $260 \times 260 \times 520$ мм. 
В Республике Таджикистан (РТ) в те годы не было опыта изготовления ни кремния технического или полупроводникового качества, ни СЭ, и поэтому было принято решение о привлечении специалистов Института ионно-плазменных и лазерных технологий АН РУз (тогда Института электроники им. У.А.Арифова АН РУз) для освоения производства вторичного литого поликристаллического кремния (ВЛПК) и СЭ на его базе.

Ниже кратко описаны технология и результаты наших совместных научнопрактических работ.

Слитки ВЛПК заданной формы получали на установках типа С-3179, которые первоначально предназначались для использования в качестве кремниевых матриц, а затем использовали на заводе «Кристалл» г. Ташкумыр, Кыргызстан для изготовления кварцевых тиглей большой емкости методом высокотемпературного синтеза из парогазовых смесей $\left(\mathrm{SiCl}_{4}+\mathrm{H}_{2}+\mathrm{O}_{2}\right)$ с осаждением образующейся двуокиси кремния на поверхности кремниевой матрицы. Установка была переделана для прямого литья в вакууме слитков ВЛПК с формой и электрофизическими характеристиками, приемлемыми для последующего изготовления на этой основе подложек СЭ.

Каркас установки представлял собой металлоконструкцию, выполненную из двух силовых рам, стянутых между собой болтами, на которой были установлены все основные узлы и системы. На низкой раме была установлена рабочая камера, на высокой - гидроколонна. С двух сторон к низкой раме притянуты болтами площадки обслуживания с оградительными перилами, а с третьей - каркас, на котором крепилось основное оборудование. Основные узлы и элементы для проведения технологического процесса размещали в рабочей камере, которая включала в себя верхнюю, среднюю и нижнюю царги, крышку и днище.

В верхней части рабочей камеры размещены графитовый плавильный нагреватель, снабженный водоохлаждаемыми токовводами верхней царги, боковой тепловой экран с закрепленной на нем в несколько слоев графитизированной тканью и верхний тепловой экран. В нижней части рабочей камеры размещены графитовый сборный подогревной нагреватель, также снабженный водоохлаждаемыми токовводами нижней царги, боковой тепловой экран, опирающийся на кольцо, поддерживаемое тремя опорными графитовыми скобами. На трех опорах средней царги установлен верхний тепловой экран подогревного нагревателя изложницы и снабженный сливной кремниевой пробкой кварцевый тигель, который конструктивно входит внутрь плавильного нагревателя. На двух охлаждаемых токовводах средней царги закреплен графитовый нагреватель, предназначенный для выплавления кремниевой пробки. Для наблюдения за процессом слива расплава предусмотрено смотровое окно. Боковые поверхности царги имеют рубашки охлаждения штуцера подвода и отвода хладоагента. Крышка камеры также имеет рубашку водоохлаждения и штуцер подачи в камеру инертного газа, а также термопарный ввод для замера температуры расплава.

Для вертикального перемещения элементов рабочей камеры в конструкции предусмотрена гидроколонна. Подъем верхней царги (вместе с крышкой) позволяет производить загрузку тигля, подъем всех царг - съем или установку литейной формы-изложницы. Гидроколонна представляет собой цилиндрический корпус, внутри которого на двух подшипниках скольжения перемещается плунжер. В верхнем и нижнем фланцах корпуса размещены уплотнительные манжеты. 
Операция подготовки плавок кремниевых блоков для СЭ включает в себя выборку из сырья $p$-типных отходов кремниевых производств по знаку термо-ЭДС или трехзондовым методом, а также подлегирование шихты до заданного номинала добавкой $p^{+}$-типных отходов производств кремниевых однослойных эпитаксиальных структур (КОЭС) $p-p^{+}$.

Вес лигатуры рассчитывали по формуле

$$
\frac{P_{3}\left(\Pi_{\kappa p}-\Pi_{u .3 .}\right)}{K_{э \phi} \Pi_{л}},
$$

где $P_{3}-$ вес исходной загрузки в граммах; $\Pi_{\kappa p}-$ концентрация легирующей примеси в получаемой отливке, атом $/ \mathrm{cm}^{3} ; \Pi_{u .3 .}-$ концентрация легирующей примеси в исходной загрузке, атом $/ \mathrm{cm}^{3} ; K_{э \phi}$ - эффективный коэффициент распределения бора в кремнии, $K_{\ni}=0.9 ; \Pi_{l}-$ концентрация легирующей примеси в лигатуре, атом $/ \mathrm{cm}^{3}$.

Упрощенно процесс получения ВЛПК можно описать следующим образом [2]. Плавка ведется в вакууме $5 \times 10^{-2}$ мм рт.ст. с использованием графитовых прямонакальных нагревателей. После выдержки расплава в плавильном тигле с нагревателем, включением другого нагревателя расплавляется кремниевая пробка литника и расплав стекает в литьевую форму-изложницу, также снабженную отдельным нагревателем. Расплав кристаллизуется послойно от дна формы к свободной поверхности. Длительность выдержки расплава в изложнице, т.е. фактически скорость кристаллизации, является одной из основных технологических характеристик процесса, поскольку определяет размеры зерен ВЛПК, величина которых должна была превыщать 300 мкм. Установленный опытным путем оптимальный диапазон длительности выдержки расплава лежит в пределах 1.5-2 ч, при этом размеры отдельных зерен гарантировано превышали 2 мм по основному объему слитка, за исключением краевых областей вдоль поверхностей, контактировавших со стенками и днищем графитовой изложницы.

После получения каждого слитка ВЛПК (рис. 1) проводили визуальные и микроскопические исследования поверхности для выявления различных макродефектов, затем после обрезки слитка со всех сторон на глубину 10 мм определяли тип проводимости продукта и его удельное сопротивление, а также его разброс по объему. Характерными структурными дефектами роста ВЛПК являются дислокации, проявляющиеся в виде дислокационных ямок травления и сеток, различные дефекты роста типа пирамид и трипирамид и, конечно, границы зерен, в основном определяющие скорость рекомбинации носителей тока в этом материале.

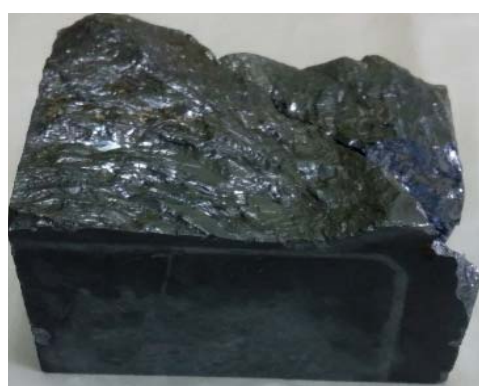

Рис. 1. Готовый слиток ВЛПК в разломе. 
Слитки ВЛПК распускали на пластины толщиной 300 мкм, из которых изготавливали подложки для СЭ двух типоразмеров.

Геометрия фронтального контакта СЭ из ВЛПК размером $2 \times 4 \mathrm{~cm}^{2}$, как и размером $4 \times 8 \mathrm{~cm}^{2}$ представляла собой серию параллельных полосок с шагом $0.5 \mathrm{~cm}$ c пересекающей их центральной токосборной шиной. На готовых $\mathrm{CЭ} \mathrm{c}$ просветляющим покрытием, подложки для которых были предварительно подвергнуты шлифовке, полировке и химическому травлению с последующим созданием $p$ - $n$ перехода ионной имплантацией или диффузией фосфора на глубину 0.8-1.0 мкм, в случае водородной пассивации, был достигнут максимальный КПД, составляющий в условиях освещенности АМ 1 и АМ 1.5 соответственно 12.5\% и $11.5 \%$. КПД СЭ из ВЛПК без водородной пассивации составлял 9-10\%. Токосъемные контакты выполняли напылением композиции титан-никель-медь на фронтальную и тыльную стороны СЭ методом вакуумного напыления в едином цикле, что придает контакту требуемую механическую прочность, обеспечивает хорошую адгезию с поверхностью кремния, малое последовательное сопротивление и коррозионную стойкость. Просветляющее покрытие из $\mathrm{SiO}_{x}$ толщиной 1150 нм, дававшее прирост КПД СЭ на 12-15\%, изготавливали при $T=$ 300 К в парах тетрахлорида кремния в токе смеси увлажненного водорода с азотом.

Анализ вольтамперных характеристик СЭ из ВЛПК с $n^{+}-p$ структурой размером $2 \times 4 \mathrm{~cm}^{2}$ показал следующие типичные параметры: $I_{к 3}=23 \mathrm{~mA} / \mathrm{cm}^{2}, U_{x x}=$ $0.51 \mathrm{~B}$, коэффициент заполнения $f f=0.6, R_{s}=50 \pm 10 \mathrm{Oм} /$ кв при температуре $25^{\circ} \mathrm{C}$ и освещении вольфрамовой лампой с $P=0.1 \mathrm{BT} / \mathrm{cm}^{2}$.

Исследование тестовых $p$ - $n$-структур, изготовленных из обрезаемых краевых областей слитка ВЛПК, показало высокую концентрацию локальных включений, преобладание мелких, менее 100 мкм, зерен, а также то обстоятельство, что их коэффициент выпрямления обнаруживал очень сильную зависимость от температуры по сравнению с аналогичными диодными структурами из других видов поликристаллического кремния, а также из ВЛПК, но без упомянутых дефектов. Этот факт был использован нами при создании нового полупроводникового прибора - защитного устройства нити ламп накаливания (ЗУЛН) [3], представлявшего собой диод с площадью $p$ - $n$-перехода $5 \times 5 \mathrm{~mm}^{2}$, размещаемый на торце цокольного контакта лампы, с резко ухудшающимися по мере нагрева пропускаемым током выпрямляющими свойствами. То есть ЗУЛН гарантировано срезал наполовину величину пускового тока, а в установившемся режиме лампа горела не в полнакала, как у всех известных подобных устройств, а на полную свою номинальную мощность.

Было также создано переносное зарядное устройство, укомплектованное СЭ из ВЛПК [4] и ряд других приборов, включая СЭ для преобразования концентрированного солнечного излучения (КСИ) с повышенной эффективностью в диапазоне КСИ 5-10 крат, а также нагреватели для бытовых приборов, однако их серийное производство, кроме ЗУЛН, наладить не удалось по той простой причине, что после разрыва хозяйственных связей между бывшими республиками СССР на ЛКРМ прекратилась отгрузка отходов кремниевых производств, находившихся в основном на Украине и в России.

В этой ситуации с учетом проведения успешных опытов по получению первого во всей Центральной Азии ТК из местного сырья [5], в Таджикистане, как и ранее в Узбекистане, началось проведение научных и опытно-промышленных работ по 
получению ТК на основе изучения и использования существующих в наших странах сырьевых ресурсов.

Основные результаты, полученные в Узбекистане, приведены и подробно обсуждены в [6, 7]. Ниже впервые приведены данные, полученные в Таджикистане, в рамках «Целевой комплексной программы по широкому использованию возобновляемых источников энергии, таких как энергия солнца, ветра, биомассы, энергия подземных источников», согласно которой были исследованы сырьевые ресурсы Северного Таджикистана.

Указанный регион чрезвычайно богат кремнеземными ресурсами. На его территории геологами выявлены десятки проявлений и месторождений кварцевого сырья различных генетических типов, в том числе: осадочных кварцевых песков (Курганчи), связанных с палеогеновыми морскими отложениями; гидротермальных кварцевых жил и зон прожилкования и окварцевания (Шокадам-Булак, Кансай, Канджол, Такели и др.), связанных с магматическими эманациями: вулканогенно-гидротермальных вторичных кварцитов (Тутлы-Кудук, Токмак и др.), связанных с гипогенным окварцеванием верхнепалеозойских вулканитов.

Наиболее перспективным для разработки представляется Шокадамбулакское месторождение, где жильный кварц (ЖК) представлен многими генерациями. В отдельных пробах ЖК спорадически в ничтожном количестве встречаются галенит, пирит, гематит, барит, а также золото и серебро. Удельный вес массивного ЖК

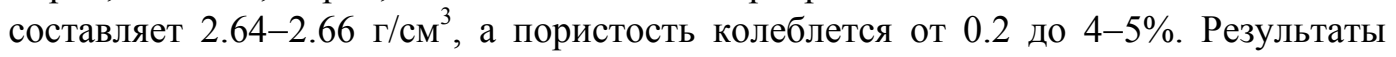
химического анализа состава этого ЖК представлены в табл. 1 в сопоставлении с данными по месторождениям Узбекистана $[6,7]$ и данным геологов по известным месторождениям Казахстана и России, сырье из которых используется для получения ТК. В генетическом отношении Шокадамбулакское месторождение относится к гидротермальному типу. Суммарные разведанные запасы ЖК только по его восточному участку составляют 1412 тыс.т., в том числе по категориям А. В и $\mathrm{C}_{1}$ соответственно 480, 530, 402 тыс.т.

Таблица 1. Химический состав кварцев и кварцитов различных месторождений.

\begin{tabular}{l|c|c|c|c|c}
\hline \multicolumn{1}{c|}{ Наименование } & \multicolumn{5}{c}{ Химический состав, \% } \\
\cline { 2 - 6 } \multicolumn{1}{c}{ месторождений } & $\mathrm{SiO}_{2}$ & $\mathrm{Al}_{2} \mathrm{O}_{3}$ & $\mathrm{Fe}_{2} \mathrm{O}_{3}$ & $\mathrm{CaO}$ & $\mathrm{MgO}$ \\
\hline Баническое (Россия) & 98.9 & 0.4 & 0.18 & 0.11 & Сл. \\
Надырбай (Казахстан) & 98.8 & 0.25 & 0.26 & - & - \\
Заргарское (Узбекистан) [6, 7] & 98.9 & 0.1 & 0.4 & 0.3 & 0.1 \\
Шокадамбулакское (Таджикистан) & 98.6 & $0.22-1.54$ & - & $0.06-0.89$ & - \\
\hline
\end{tabular}

Как известно, не меньшее влияние на чистоту ТК и экономические и экологические показатели его производства оказывает второй главный компонент электродуговой плавки - углеродистый восстановитель (УВ).

Лучшим УВ является древесный уголь, однако он в регионе не производится и перед технологами Таджикистана, как ранее перед коллегами из Узбекистана [6, 7], встала задача найти ему равноценную замену на основе местного сырья. Для Таджикистана перспективным, на наш взгляд, является применение антрацитов, в частности, из Назарлокского месторождения, характеристики которого приведены в табл. 2. Видно, что данный антрацит не уступает по качеству таковому из 
знаменитого вьетнамского месторождения Ха-Ту, а по величине зольности сопоставим с древесным углем.

Таблица 2. Технические характеристики антрацита из Назарайлокского месторождения.

\begin{tabular}{c|c|c|c}
\hline Зольность, \% & $\begin{array}{c}\text { Массовая } \\
\text { доля общей } \\
\text { влаги, \% }\end{array}$ & $\begin{array}{c}\text { Массовая } \\
\text { доля серы, \% }\end{array}$ & $\begin{array}{c}\text { Выход } \\
\text { летучих } \\
\text { веществ, \% }\end{array}$ \\
\hline $1.2-4.2$ & $0.78-4.66$ & $0.13-0.62$ & $3.0-5.0$ \\
\hline
\end{tabular}

Петрографическое изучение показало, что эти угли дюрено-клареновые. Площадь залежей составляет 25 км $^{2}$ с протяженностью $\sim 10$ км. В угленосной толще выявлены 16 угольных пластов полого-наклонного падения, мощностью 1.3-9.0 м; из них 9 являются антрацитами, остальные каменноугольные. Прогнозные ресурсы антрацитов оцениваются в 450 млн тонн, из них 60\%, причём самые высококачественные, сосредоточены в 2-3 пластах.

Таким образом, результаты работ по ВЛПК, а затем по ТК в совокупности с комплексной оценкой местных сырьевых ресурсов, явились основой создания нового научного направления, изучающего технологию и электрофизические свойства немонокристаллических модификаций кремния, a также были использованы при формулирке технико-экономического обоснования на строительство в регионе предприятий по выплавке ТК и кремнистых сплавов.

\section{ЛИТЕРАТУРА}

1. B.M. Abdurakhmanov, T.Kh. Achilov, A.L. Kadirov, Sh.T. Kasimov, M.S. Saidov, V.Y. Tajiev, M. Khalikov, S. Khoshimov, O.I. Chechetka, Applied Solar Energy 28, №4, 9 (1992).

2. А.Л. Кадыров. Исследование электрофизических свойств вторичного литого поликристаллического кремния и солнечных элементов на его основе. Автореферат дисс. доктора. физ.-мат. наук (Худжанд, 2018).

3. Б.М. Абдурахманов, А.Л. Кадыров, М.Ф. Умаров, Ученые записки ХГУ им. акад. Б. Гафурова №5, 12-19 (2012).

4. Ф.Х. Махмудов, Б.М. Абдурахманов. Осветительное устройство. Патент РУз (дастлабки) №695

5. B.M. Abdurakhmanov, K.P. Abdurakhmanov, B.V. Gugushvili, A.L. Kadirov et al, Applied Solar Energy 39, №2, 102 (2003).

6. Б.М. Абдурахманов, Х.Б. Ашуров, М.Ш. Курбонов. Химико-металлургический передел кремнезема в моносилановое сырье для солнечной энергетики и наноэлектроники (Из-во «Navroz», Ташкент, 2018).

7. М.Ш. Курбонов. Совершенствование технологии выплавки технического кремния и кремнистых сплавов. Автореферат диссертации доктора (DSc) технических наук (Ташкент, 2018). 